ACTA AGROBOTANICA

Vol. 46, z. 2 - 1993

$5-13$

\title{
The physiology of extremely desiccated Brassica juncea (L) seeds
}

\section{SAVITA KHATTRA, KIRANJYOTI SHARMA AND GURMIT SINGH*}

Department of Botany, *Department of Seed Science and Technology, Punjab Agricultural University, Ludhiana 141004 , India

(Received: September 10, 1992)

A b s t a r c t

Seeds of four raya cvs., viz. RL 1359, RLM 198, RLM 619 and RLM 514 were desiccated for 2 , 7,15 and 45 days wchich led to different levels of seed moisture. Data on germination capacity speed of germination, seedling dry weight, electrical conductance, dehydrogenase activity and seed storage behaviour for up to two years after desiccation were recorded. Based on this data, cvs. RL 1359 and RLM 514 were found to be tolerant to desiccation to as low as 0.73 and 1.16 per cent seed moisture levels, respectively. Seeds of RLM 198 tolerated desiccation up to 2.28 per cent seed moisture. However, RLM 619 seeds showed desiccation injuries in seedling dry weight, electrical conductance and speed of germination at moisture levels below 5.67 per cent.

\section{INTRODUCTION}

Orthodox seeds show improved storability on desiccation to between $14-5$ per cent seed moisture (H a r r i n g t o n, 1960). Such treatment can be useful to preserve the carryover seed lots and elite material in sealed storage for longer durations. The lower limits of seed moisture for hermetic sealing, given by the Federal Seed Act (U. S. Dept. Agric. 1968) appear to be quite high and can be reduced further without causing injurious effects in the seeds. There are four studies on the physiology of extremely desiccated seeds ( $\mathrm{K}$ h a $\mathrm{t} t \mathrm{r}$ a et al., 1991) and those that have been conducted have indicated induction of injuries in the seeds immediately after desiccation. These observations cannot be generalized for all crop seeds since various seeds respond differently to equivalent levels of seed desiccation. Brassica juncea seeds show satisfactory storage only for one season after harvest under ordinary storage conditions. Therefore, the physiology of extremely desiccated seeds was investigated in order to locate the level of injuries in the seed due to such low moisture levels. 


\section{MATERIALS AND METHODS}

Seeds of Brassica juncea (L.) cultivars RL 1359, RLM 198, RLM 619 and RLM 514 were obtained immediately after harvest from the Dept. of Plant Breeding, PAU, Ludhiana, India. The seeds had the following respective moisture levels: 5.55, 5.90, 5.67 , and 5.66 per cent. Healthy and uniform by sized seeds of all the cultivars were desiccated to different seed moisture levels on fused calcium chloride in desiccators for $2,7,15$ and 45 days at $32 \pm 2^{\circ} \mathrm{C}$ and the seed moisture percentage was determined by drying the seeds in an oven at $105 \pm 1^{\circ} \mathrm{C}$ for $17 \mathrm{~h}$. After the prescribed period of desiccation, the seeds were hermetically sealed in brown glass bottles and stored at room temperature. Seed germination in triplicate lots of hundred seed each was tested on paper towels at $25 \pm 1^{\circ} \mathrm{C}$ in a Biological Oxygen Demand (B.O.D.) incubator. Per cent germination was counted daily up to day 7 of germination. Speed of germination was calculated after A $\mathrm{g} \mathrm{r}$ a w a $l$ and D a d $\mathrm{l}$ a $\mathrm{n}$ i (1984). The root and shoot lengths were measured on the 7 th day of germination. On the 7 th day, ten seedlings from each replicate were dried at $80 \pm 2^{\circ} \mathrm{C}$ for $48 \mathrm{~h}$ in a hot air oven and their dry weight was recorded. Membrane leakage was measured indirectly by measuring solute efflux (EC) of the seed leachate using a Digital conductivity meter (Naina Digital Conductance meter 733). Total dehydrogenase activity was measured with the TTC test (A 1 o $\mathrm{n} \mathrm{i,}$ 1982). Crushed seeds ( $200 \mathrm{mg}$ ) were incubated in $3 \mathrm{ml}$ of 0.08 per cent $2,3,5$ triphenyl tetrazolinum chloride solution $(0.05 \mathrm{M}$ potassium phosphate buffer, $\mathrm{pH} 7,4)$ at $25^{\circ} \mathrm{C}$ for $4 \mathrm{~h}$ in the dark in a B.O.D. incubator. Red colour so developed was eluted in acetone and read at $485 \mathrm{~nm}$. Seed germination, speed of germination and seedling dry weights were recorded at three month intervals for up to 2 years of hermetic storage.

\section{RESULTS AND DISCUSSION}

Germination capacity speed in cvs. RL 1359 and RLM 619 remained unaffected with desiccation of seeds from 5.5 to 0.73 and 5.67 to 0.7 per cent seed moisture, respectively, while both these parameters were significantly reduced in cv. RLM 198 below 2.28 per cent seed moisture. On the other hand, cv. RLM 514 registered a significant increase in both seed germination and its speed with seed desiccation below 5.6 per cent moisture. E 11 i s et al. $(1981,1982)$ showed no injuries in cassava and cowpea seeds on desiccation up to 3.2 and 4.4. per cent moisture content, respectively and the life of these desiccated seeds showed a drastic reduction in germination from 94 to 50 per cent on desiccation from 14.8 to 3.7 per cent moisture. The desiccation damage was avoided if the moisture content of seeds prior to the germination test was raised by humidification (E 1 l is et al., 1990).

Seedling performance in terms of root shoot lengths showed no deleterious effects of desiccation in all four cultivars of raya. The effect of seed desiccation was non-significant on seedling dry weights in cvs. RL 1359 and RLM 198, whereas 
cv. RLM 619 showed a significant reduction in the seedling dry weights with desiccation. However, in cv. RLM 514, seedling dry weight increased significantly with seed desiccation.

Seed vigour in term of root/shoot dry weights was reduced with desiccation in soybean and pigeonpea seeds while in case of wheat no such reduction was observed on extreme seed desiccation ( $\mathrm{K} \mathrm{h}$ a $t \mathrm{t} \mathrm{r}$ a et al., 1991). N u t i l e (1964) reported that soybean seeds dehydrated to 3.0 per cent moisture showed delayed germination and produced seedlings with deformed radicles.

Electrical conductance is an indirect measure of membrane integrity. As seeds dry out the cell membranes lose their integrity and solute leak out rapidly in pea embryos ( $\mathrm{S}$ i mon s and R a j a $\mathrm{H}$ a r u n, 1972). Increased electrical conductance reflected injury of cell membranes in the present study because electrical conductance in cvs. RLM 198 and RLM 619 increased with increased desiccation levels. Solute leakage was proportional to the degree of seed hydration in cotton and pea seeds ( $\mathrm{S}$ i $\mathrm{m} \mathrm{m}$ on and $\mathrm{W}$ e i b e, 1975). In soyabean and pigeonpea seeds, desiccation injury was expressed through increased solute efflux with progressive desiccation ( $\mathrm{K} \mathrm{h}$ a $t \mathrm{t} \mathbf{r}$ a et al., 1991). Electrolyte leakage from seeds of cv. RL 1359 remained unaffected while cv. RLM 514 showed a significant decline in electrolyte leaching with increased desiccation. Such observations point to the maintenance/ improvement of membrane permeability and thus no injury. Similar observations were recorded in the case of wheat seeds which were considered to be desiccation tolerant (K h a t $t \mathrm{r}$ a et al., 1991).

Desiccation of cvs. RL 1359, RLM 198 and RLM 619 seeds had no effect on dehydrogenase activity, while cv. RLM 514 seeds recorded a significant rise in this activity with desiccation. $\mathrm{K}$ h a $\mathrm{t} t \mathrm{r}$ a et al. (1991) reported no change in dehydrogenase activity in wheat seeds with desiccation to about 1.0 per cent seed moisture. Increase in dehydrogenase activity in RLM 514 is an indication of high vigour of the low moisture seeds compared to non-desiccated seeds. B u r r is et al. (1969) showed a positive correlation between tetrazolium staining with seed quality and subsequent seedling vigour in naturally and artificially aged soyabean seeds.

In storage the non-desiccated seeds of all four cultivars showed a reduction in per cent germination, wereas no such reduction with storage for up to two years was shown in the desiccated seeds of these cultivars, except in cv. RLM 198 where seeds at 1.07 per cent moisture level registered a decline in their germination capacity (Table 2). It is significant to notice that the desiccated seeds invariably maintained a higher germination capacity their respective controls at equivalent stages of storage. At respective intervals of seed storage, speed of germination was higher in the desiccated seeds of cvs. RL 1359, RLM 198 and RLM 514 as compared to their non-desiccated seeds at a comparable stage of storage, while in cv. RLM 619 desiccated seeds kept a lower speed of germination when compared to that in its non-desiccated ones (Table 3).

The dry weights of seedlings raised from stored seeds were comparable at respective storage periods in desiccated and non-desiccated seeds in cv. RL 1359 (Table 4). 
Table 1

Effect of desiccation on germination capacity, speed of germination. root and shoot lenght, seedling dry weight, electrolyte leakage and dehydrogenase activity

\begin{tabular}{|c|c|c|c|c|c|c|c|c|}
\hline Cultivar & $\begin{array}{c}\text { Moisture content } \\
(\%)\end{array}$ & $\begin{array}{c}\text { Germination } \\
(\%)\end{array}$ & $\begin{array}{l}\text { Speed of } \\
\text { germination }\end{array}$ & $\begin{array}{l}\text { Root length } \\
(\mathrm{cm})\end{array}$ & $\begin{array}{l}\text { Shoot length } \\
(\mathrm{cm})\end{array}$ & $\begin{array}{l}\text { Seedling } \\
\text { dry weight } \\
\text { (mg) }\end{array}$ & $\begin{array}{l}\text { Electrolyte } \\
\text { leakage } \\
\text { umho`s } 24 \text { h }^{-1} \\
50 \text { seeds }\end{array}$ & $\begin{array}{l}\text { Dehydrogenase } \\
\text { activity } \\
\text { OD } 200 \mathrm{mg}^{-1} \mathrm{~h}^{-1}\end{array}$ \\
\hline \multirow[t]{5}{*}{ RL 1359} & 5.55 & 92.6 & 56.8 & 10.49 & 4.19 & 38 & 47.1 & 0.040 \\
\hline & 2.74 & 92.6 & 59.8 & 11.45 & 4.21 & 38 & 47.3 & 0.030 \\
\hline & 2.19 & 92.3 & 61.0 & 11.56 & 4.13 & 39 & 46.8 & 0.030 \\
\hline & 0.73 & 92.0 & 62.2 & 9.67 & 4.11 & 37 & 47.5 & 0.040 \\
\hline & $\mathrm{CD}(0.05)$ & NS & NS & 1.01 & $\mathrm{NS}$ & NS & NS & NS \\
\hline \multirow[t]{5}{*}{ RLM 198} & 5.90 & 96.0 & 66.1 & 11.28 & 5.25 & 19 & 30.3 & 0.037 \\
\hline & 2.92 & 96.0 & 71.8 & 10.16 & 4.65 & 19 & 30.6 & 0.036 \\
\hline & 2.28 & 92.0 & 61.5 & 10.68 & 4.60 & 18 & 39.4 & 0.041 \\
\hline & 1.07 & 88.0 & 67.8 & 9.47 & 4.57 & 17 & 34.0 & 0.041 \\
\hline & $\mathrm{CD}(0.05)$ & 4.16 & 2.61 & $\mathrm{NS}$ & NS & NS & 0.76 & NS \\
\hline \multirow[t]{5}{*}{ RLM 619} & 5.67 & 98.0 & 64.6 & 11.14 & 3.33 & 34 & 30.8 & 0.091 \\
\hline & 2.59 & 95.3 & 50.2 & 9.41 & 2.84 & 25 & 35.7 & 0.080 \\
\hline & 2.10 & 95.3 & 53.1 & 9.80 & 2.25 & 28 & 44.2 & 0.080 \\
\hline & 0.70 & 96.0 & 54.6 & 9.35 & 2.21 & 25 & 36.2 & 0.090 \\
\hline & $\mathrm{CD}(0.05)$ & NS & NS & NS & NS & 6.50 & 6.18 & $\mathrm{NS}$ \\
\hline \multirow[t]{5}{*}{ RLM 514} & 5.60 & 89.3 & 83.0 & 10.23 & 4.80 & 17 & 32.6 & 0.055 \\
\hline & 2.69 & 96.6 & 93.0 & 10.29 & 4.93 & 24 & 27.3 & 0.058 \\
\hline & 1.97 & 95.3 & 91.0 & 10.56 & 4.93 & 21 & 25.0 & 0.068 \\
\hline & 1.16 & 91.3 & 89.0 & 11.22 & 3.82 & 24 & 24.2 & 0.073 \\
\hline & $\mathrm{CD}(0.05)$ & NS & NS & NS & & 4.43 & & 0.010 \\
\hline
\end{tabular}


Table 2

Germination capacity of Brassica juncea (L.) cultivar seeds at differend levels of moisture and intervals (months)

\begin{tabular}{|c|c|c|c|c|c|c|c|c|c|c|}
\hline Cultivar & $\begin{array}{c}\text { Moisture } \\
(\%)\end{array}$ & \multicolumn{9}{|c|}{ Storage Period (month) } \\
\hline \multirow[t]{3}{*}{ RL 1359} & 5.55 & $92.6 \pm 2.8$ & $92.3 \pm 3.6$ & $94.0 \pm 1.7$ & $93.0 \pm 2.0$ & $94.0 \pm 2.6$ & $83.0 \pm 2.6$ & $82.0 \pm 2.6$ & $82.0 \pm 1.5$ & $80.0 \pm 2.6$ \\
\hline & 2.74 & $92.6 \pm 2.3$ & $92.7 \pm 2.0$ & $95.0 \pm 1.0$ & $95.3 \pm 2.6$ & $95.0 \pm 2.6$ & $94.0 \pm 3.6$ & $94.7 \pm 2.0$ & $96.0 \pm 1.2$ & $96.0 \pm 1.7$ \\
\hline & 2.19 & $92.3 \pm 2.0$ & $93.0 \pm 3.0$ & $94.0 \pm 1.7$ & $95.3 \pm 3.6$ & $94.3 \pm 2.0$ & $95.0 \pm 1.0$ & $95.0 \pm 2.6$ & $93.0 \pm 3.0$ & $92.0 \pm 2.6$ \\
\hline \multirow[t]{4}{*}{ RLM 198} & 5.90 & $96.0 \pm 1.5$ & $94.7 \pm 2.0$ & $95.0 \pm 2.0$ & $95.3 \pm 1.0$ & $94.0 \pm 2.1$ & $84.0 \pm 1.0$ & $80.0 \pm 2.6$ & $81.7 \pm 2.0$ & $78.0 \pm 1.5$ \\
\hline & 2.92 & $96.0 \pm 0.6$ & $96.3 \pm 2.0$ & $96.3 \pm 1.0$ & $94.0 \pm 2.0$ & $95.0 \pm 2.6$ & $95.0 \pm 2.0$ & $92.0 \pm 2.7$ & $88.0 \pm 3.6$ & $88.0 \pm 2.6$ \\
\hline & 2.28 & $92.0 \pm 1.7$ & $92.3 \pm 2.0$ & $93.0 \pm 2.0$ & $91.3 \pm 2.3$ & $93.0 \pm 2.0$ & $92.0 \pm 2.0$ & $90.0 \pm 2.1$ & $82.3 \pm 1.6$ & $82.0 \pm 1.0$ \\
\hline & 1.07 & $88.0 \pm 1.7$ & $87.0 \pm 3.0$ & $85.0 \pm 2.0$ & $83.0 \pm 1.6$ & $83.0 \pm 1.8$ & $84.3 \pm 4.5$ & $83.0 \pm 2.0$ & $81.0 \pm 2.3$ & $81.0 \pm 2.5$ \\
\hline \multirow{2}{*}{ RLM 619} & 2.10 & $95.3 \pm 2.8$ & $93.30 \pm 2.0$ & $94.0 \pm 1.6$ & $92.3 \pm 2.0$ & $9 ? 0 \pm 1.0$ & $93.0 \pm 2.0$ & $92.0 \pm 2.6$ & $93.3 \pm 1.0$ & $93.0 \pm 2.0$ \\
\hline & 0.70 & $96.0 \pm 0.6$ & $96.7 \pm 3.8$ & $93.0 \pm 1.7$ & $91.0 \pm 2.0$ & $3 \pm 1.7$ & $90.0 \pm 2.1$ & $89.0 \pm 1.5$ & $90.0 \pm 3.0$ & $88.0 \pm 2.0$ \\
\hline \multirow[t]{4}{*}{ RLM 514} & 5.60 & $89.3 \pm 2.6$ & $87.0 \pm 2.0$ & $84.0 \pm 1.7$ & $81.3 \pm 3.6$ & $82.0 \pm 1.0$ & $83.0 \pm 1.5$ & $80.0 \pm 2.0$ & $80.0 \pm 1.7$ & $80.0 \pm 2.0$ \\
\hline & 2.69 & $96.6 \pm 2.0$ & $96.3 \pm 2.0$ & $94.0 \pm 1.7$ & $95.7 \pm 2.0$ & $95.0 \pm 1.7$ & $96.0 \pm 2.5$ & $94.0 \pm 2.6$ & $95.0 \pm 2.0$ & $95.0 \pm 1.7$ \\
\hline & 1.97 & $95.3 \pm 1.0$ & $95.3 \pm 2.8$ & $94.0 \pm 2.6$ & $94.0 \pm 3.0$ & $96.0 \pm 1.0$ & $95.0 \pm 1.6$ & $94.0 \pm 1.7$ & $93.0 \pm 1.7$ & $94.0 \pm 1.0$ \\
\hline & 1.16 & $91.3 \pm 2.3$ & $90.3 \pm 2.0$ & $91.0 \pm 2.1$ & $89.7 \pm 3.0$ & $90.0 \pm 2.1$ & $90.3 \pm 1.6$ & $90.0 \pm 2.0$ & $89.0 \pm 2.0$ & $90.0 \pm 1.0$ \\
\hline
\end{tabular}


Table 3

Speed of germination (SG) of Brassica juncea (L.) cultivar seeds at differend levels of moisture and intervals (months)

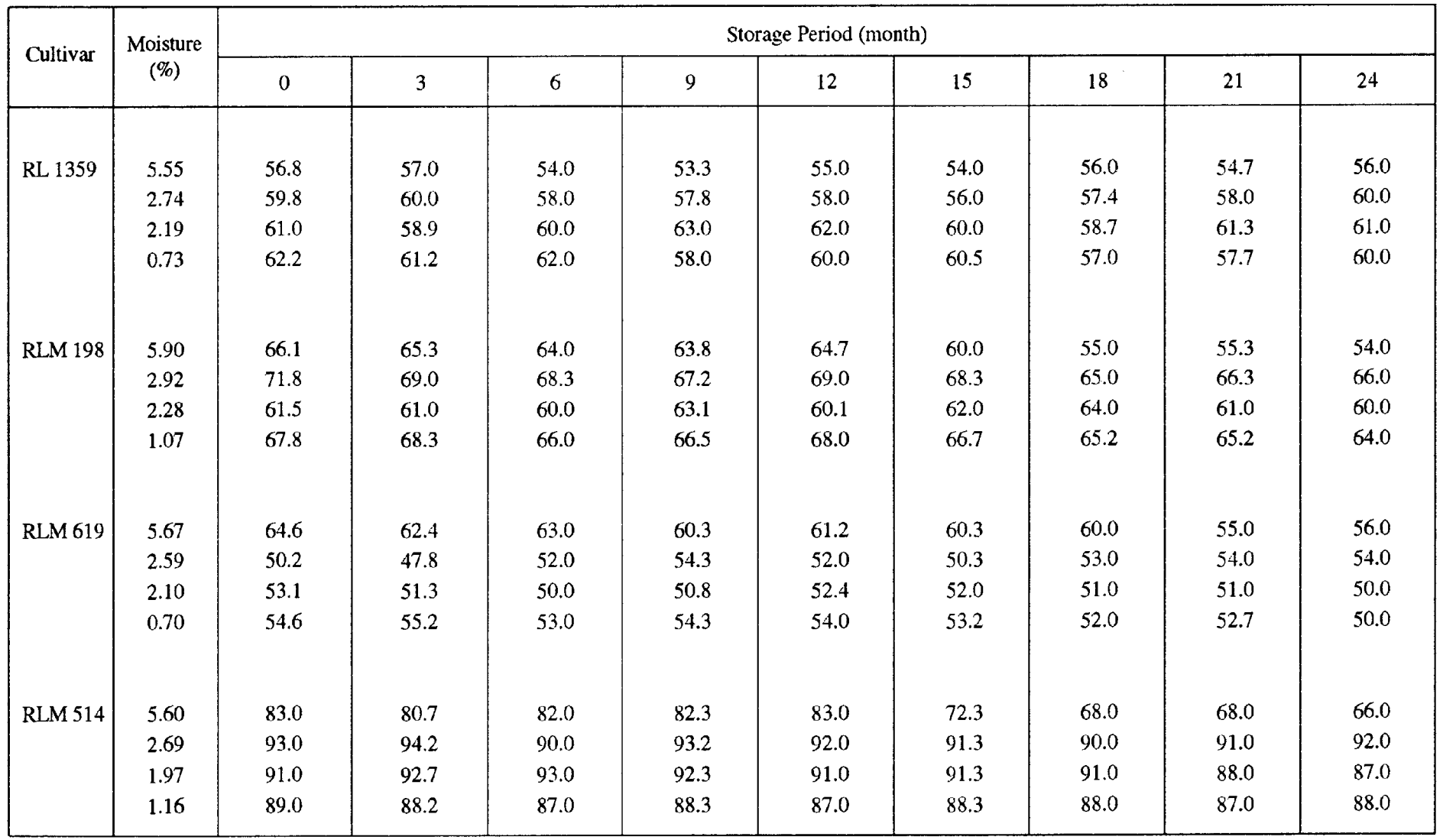


Ta b le 4

Seedling dry weight of Brassica juncea (L.) cultivar seeds at differend levels of moisture and intervals (months)

\begin{tabular}{|c|c|c|c|c|c|c|c|c|c|c|}
\hline \multirow{2}{*}{ Cultivar } & \multirow{2}{*}{$\begin{array}{c}\text { Moisture } \\
(\%)\end{array}$} & \multicolumn{9}{|c|}{ Storage Period (month) } \\
\hline & & 0 & 3 & 6 & 9 & 12 & 15 & 18 & 21 & 24 \\
\hline \multirow[t]{3}{*}{ RL 1359} & 5.55 & $38.0 \pm 1.5$ & $36.0 \pm 4.0$ & $36.0 \pm 1.0$ & $35.3 \pm 1.1$ & $35.0 \pm 2.0$ & $34.0 \pm 2.6$ & $31.0 \pm 1.0$ & $33.0 \pm 2.6$ & $33.0 \pm 2.0$ \\
\hline & 2.74 & $38.0 \pm 1.7$ & $38.3 \pm 1.5$ & $39.0 \pm 1.0$ & $38.0 \pm 1.0$ & $40.0 \pm 1.5$ & $38.0 \pm 2.0$ & $37.7 \pm 1.0$ & $37.0 \pm 1.0$ & $38.0 \pm 1.2$ \\
\hline & 2.19 & $39.0 \pm 1.6$ & $37.7 \pm 2.0$ & $39.0 \pm 1.5$ & $40.3 \pm 3.0$ & $41.0 \pm 1.0$ & $38.0 \pm 2.6$ & $35.3 \pm 1.7$ & $36.0 \pm 1.0$ & $36.0 \pm 1.2$ \\
\hline \multirow[t]{4}{*}{ RLM 198} & 5.90 & $19.0 \pm 2.0$ & $18.3 \pm 2.0$ & $19.0 \pm 1.5$ & $19.7 \pm 1.1$ & $18.0 \pm 1.0$ & $17.0 \pm 2.6$ & $18.0 \pm 2.0$ & $17.0 \pm 1.0$ & $17.0 \pm 2.6$ \\
\hline & 2.92 & $19.0 \pm 2.3$ & $19.0 \pm 1.0$ & $18.0 \pm 1.7$ & $17.0 \pm 1.0$ & $17.3 \pm 1.1$ & $16.0 \pm 2.7$ & $18.0 \pm 1.0$ & $18.3 \pm 1.3$ & $20.0 \pm 1.7$ \\
\hline & 2.28 & $18.0 \pm 2.0$ & $17.7 \pm 2.0$ & $18.0 \pm 1.0$ & $20.0 \pm 2.0$ & $17.3 \pm 1.0$ & $18.0 \pm 2.1$ & $18.7 \pm 0.6$ & $17.3 \pm 1.0$ & $17.0 \pm 1.0$ \\
\hline & 1.07 & $17.0 \pm 2.6$ & $19.3 \pm 2.0$ & $16.0 \pm 1.2$ & $17.3 \pm 1.2$ & $17.0 \pm 1.0$ & $17.0 \pm 2.0$ & $15.0 \pm 1.5$ & $13.7 \pm 0.1$ & $14.0 \pm 1.0$ \\
\hline \multirow{2}{*}{ RLM 619} & 2.10 & $28.0 \pm 1.7$ & $25.3 \pm 2.0$ & $24.0 \pm 1.0$ & $23.3 \pm 1.1$ & $23.0 \pm 1.0$ & $25.0 \pm 2.6$ & $25.0 \pm 2.0$ & $23.7 \pm 2.0$ & $21.0 \pm 1.7$ \\
\hline & 0.70 & $25.0 \pm 1.7$ & $23.0 \pm 2.6$ & $24.0 \pm 2.0$ & $21.3 \pm 1.0$ & $22.0 \pm 1.7$ & $24.0 \pm 1.5$ & $22.0 \pm 1.0$ & $19.0 \pm 1.7$ & $18.0 \pm 2.0$ \\
\hline \multirow[t]{4}{*}{ RLM 514} & 5.60 & $17.0 \pm 2.0$ & $17.3 \pm 0.6$ & $18.3 \pm 1.2$ & $18.0 \pm 3.6$ & $15.0 \pm 1.0$ & $14.0 \pm 2.0$ & $14.7 \pm 1.5$ & $15.0 \pm 1.0$ & $15.0 \pm 1.7$ \\
\hline & 2.69 & $24.0 \pm 1.0$ & $25.0 \pm 2.0$ & $23.0 \pm 1.3$ & $21.7 \pm 1.2$ & $24.0 \pm 1.7$ & $23.3 \pm 2.6$ & $21.3 \pm 2.0$ & $22.0 \pm 2.1$ & $23.0 \pm 2.6$ \\
\hline & 1.97 & $21.0 \pm 1.7$ & $19.3 \pm 2.9$ & $19.0 \pm 2.6$ & $17.7 \pm 1.5$ & $20.0 \pm 1.0$ & $19.0 \pm 1.7$ & $18.0 \pm 4.0$ & $21.0 \pm 2.0$ & $20.0 \pm 1.8$ \\
\hline & 1.16 & $24.0 \pm 1.0$ & $24.3 \pm 3.0$ & $22.3 \pm 1.5$ & $24.3 \pm 1.5$ & $23.0 \pm 2.1$ & $22.0 \pm 2.0$ & $21.0 \pm 1.0$ & $21.5 \pm 1.0$ & $22.0 \pm 3.4$ \\
\hline
\end{tabular}


However, in cv. RLM 514 the seedling dry weights of desiccated seeds were higher than that of non-desiccated seeds at comparable seeds storage stages, whereas in cvs. RLM 198 and RLM 619 the seedling dry weights from highly desiccated seeds (i.e. at 1.07 and 0.7 per cent moisture, respectively) were lower than those from the non-desiccated seeds at different stages of storage. The dry weights of seedlings raised from seeds at intermediate moisture levels (i.e. at 2.90 and 2.28 per cent in cv. RLM 198 and 2.59 and 2.10 per cent in RLM 619) were at par with the control. The data suggest beneficial effects of seeds desiccation for prolonged storage.

In sum, seeds of cvs. RL 1359 and RLM 514 were found to be tolerant to desiccation up to 0.73 and 1.16 percent seed moisture levels, whereas seeds of RLM 198 were desiccation tolerant up to 2.28 per cent seed moistuure and seeds ofcv. RLM 619 registered injury in terms of seedling dry weight, electrical conductance and speed of germination below 5.67 per cennt seed moisture.

\section{REFERENCES}

A g r a w a 1 P. K., and D a d l a n i M., 1984. Vigour assessment by tetrozolium staining. [In:] Manual of Techniques in Seed Science and Technology (Ed. P. K. Agrawal and M. Dadlani), pp. 63-65. Division of Seed Science and Technology. IARI, New Delhi.

A 1 o 11 i B. S., 1982. Dehydrogenase activity in dehydrated parenchyma slices probing with $2,3,5$ triphenyl tetrazolium chloride. Plant Science Letters, 26: 57-64.

B u $r$ r is J. S., Ed g e O. T. and W a h a b A. H., 1969. Evaluation of various indices of seed and seedlin vigour in soybean (Glycine max (L.) Merr.). Proc. Assoc. Off. Seed Anal. 59: 73-81.

Ell is R. H., H o n g T. D. and R o be r ts E. H., 1981. The influence of desiccation on cassava seed germination and longevity. Ann. Bot. 47: 173-175.

Ell is R. H., Ho n g T. D. and R ob e r t s E. H., 1990 Effect of moisture content and method of rehydration on the susceptibility of pea seeds to imbibition damage. Seed Sci. and Technol. 18: 131-137.

E 11 is R. H. and R oberts E. H., 1982. Desiccation, rehydration, germination of seeds of cowpea. Seed Sci. and Technol. 10: 501-508.

H a r r in g t o n J. F., 1960. Preliminary report on the relative desirability of different containers for storage of several kinds of vegetable seeds. Calif. Univ. Dept. Veg. Crops. Ser. 104. p. 3.

$\mathrm{K}$ h a t t r a S., B h a t i a R. and $\mathrm{S}$ i n $\mathrm{g} \mathrm{h}$ G., 1991. Assessment of immediate injury in seeds following extreme desiccation. Indian J. Plant Physiol. 34. 37-41.

$\mathrm{Nutil}$ e G. E., 1964. Effect of desiccation on viability of seeds. Crop Science, 4: 325-328.

$\mathrm{S}$ i $\mathrm{m}$ o n E. W. and $\mathrm{R}$ a $\mathrm{j}$ a h a r u n R. M., 1972. Leakage during seed imbibition. J. Expt. Bot. 23: 1076-1085.

$S$ i $m$ on E.W. and W i e b e H. H., 1975. Leakage during imbibition resistance to damage at low temperature and water content of pea. New Phytol. 74: 407-411.

U.S. Departme $\mathrm{n} t$ of Ag r i cu It u re, 1968. Rules and regulations of the Secretary of Agriculture under the federal Seed Act of August 9, 1939 (53 stat. 1275) 83 pp. US. Dept. Agric. Consum and Mktg. Serv. Washington, D.C.

\section{Fizjologia skrajnie przesuszonych nasion Brassica juncea (L.)}

\section{Streszczenie}

Nasiona czterech odmian: RL 1359, RLM 198, RLM 619 i RLM 514 suszono przez 2, 7, 15 i 45 dni w celu uzyskania różnego poziomu wilgotności nasion. Badano zdolność i szybkość kielkowania, suchą masę 
kiełków, stopień przewodnictwa elektrycznego, aktywnosé dehydrogenazy i zachowanie nasion podczas dwuletniego okresu przechowywania. Na podstawie tych danych ustalono, ze odmiany RL 1359, RLM 514 sa tolerancyjne na wysuszenie odpowiednio do 0,73 i $1,16 \%$ wilgotności. Nasiona odmiany RLM 198 toleruja wysuszenie do $2,28 \%$. Nasiona zaś odmiany RLM 619 przy poziomie wilgotności poniżej 5,67 \% reaguja obniżoną masą kielków, mniejszą siłą kiełkowania i gorszym przewodnictwem. 